\title{
Structure Analysis of Tropical Cyclone Hudhud Over Bay of Bengal Using WRF Model Ashik Imran ${ }^{1}$, Ishtiaque M. Syed ${ }^{1}$, S.M. Quamrul Hassan ${ }^{2}$ and Kh. Hafizur Rahman ${ }^{2}$ \\ ${ }^{I}$ Department of Physics, Dhaka University, Dhaka-1000, Bangladesh \\ ${ }^{2}$ Bangladesh Meteorological Department, Agargaon, Dhaka-1207, Bangladesh
}

( Received: 9 November 2017 ; Accepted : 20 December 2017)

\begin{abstract}
Tropical cyclones (TCs) over Bay of Bengal (BoB) have significant socio-economic impacts on the countries bordering the BoB. In this study, we have examined the structure and thermodynamic features of the TC Hudhud $\left(7^{\text {th }}-14^{\text {th }}\right.$ October, 2014) using WRF model. Simulated outputs are in good agreement with the available observations of India Meteorological Department and Joint Typhoon warning Center. At maximum intensity stage, the system's horizontal size is found around $690 \mathrm{~km}$. Wind and vorticity distributions capture the circulation of the system very well. Most strong winds of $60 \mathrm{~ms}^{-1}$ are extended vertically from $850 \mathrm{hPa}$ to about $700 \mathrm{hPa}$. Simulation has shown intensification of the system above $200 \mathrm{hPa}$ with wind speed of about $30 \mathrm{~ms}^{-1}$. Relative humidity of the order of $90 \%$ is found up to $400 \mathrm{hPa}$.
\end{abstract}

Key Words: TC, Horizontal size, Intensification, Vertical Profile.

\section{Introduction}

The Bay of Bengal (BoB) is the largest bay in the world situated in the eastern part of the North Indian Ocean (NIO). The tropical cyclones (TCs) over BoB have significant socio-economic impacts on the bordering countries especially Bangladesh, India and Myanmar. The shallow water of $\mathrm{BoB}$, low flat coastal terrain and funneling shape of the coastline can lead to the most destructive TCs. So, it is very important to extend the lead time in the prediction of tropical cyclogenesis. A TC is a large, rapidly rotating system of clouds, winds, and thunderstorms characterized by a low pressure center near the earth's surface ${ }^{1}$ that operates as a Carnot heat engine ${ }^{2}$. TCs have areas of positive near-surface vorticity ${ }^{3}$. The size ${ }^{4}$ of TCs over the NIO varies from 100 to $2000 \mathrm{~km}$ with an average of 300$600 \mathrm{~km}$. Numerical studies of TCs were started in the mid1950s with the development of a two dimensional axisymmetric hurricane model ${ }^{5}$. A number of studies of TC wind structure were performed in 1960's and 1970's based on flight level data from aircraft observations ${ }^{6}$. In the present days, with the use of some high resolution three dimensional asymmetric numerical models (e.g. WRF model) the treatment of model governing equations and hence the cyclone research has improved a lot. Fovell et al. ${ }^{7}$ simulated the hurricane 'Rita' by using WRF model with alternating Microphysical Parameterization (MP) and Cumulus Parameterization (CP) schemes. Environmental conditions such as sea surface temperature, vertical wind shear $^{8}$ and relative humidity (moisture) distribution ${ }^{9}$ are the controlling parameters for the structure and intensity of a TC. Benjamin et al..$^{10}$ found that intensity and structure of the hurricane 'Katrina' was significantly depended on the surface flux by using WRF model. Basnayak et al. ${ }^{11}$ and A. Imran et $a l .{ }^{12}$ simulated the structure and movement of cyclonic storms over the NIO by WRF-ARW model. Akhter et al. ${ }^{13}$ found better performance of WRF model than MM5 model in simulating TCs over BoB.

In this study, the Advanced Research WRF (version 3.7.1) has been used to explore the structure (horizontal \& vertical) and thermodynamic features of Very Severe Cyclonic Storm (VSCS) 'Hudhdud' that was formed over the BoB from $7^{\text {th }}$ $14^{\text {th }}$ October, 2014. The WRF model is suitable for extensive applications in the field of atmospheric research such as idealized simulations, real time weather forecasting, and data assimilation etc ${ }^{14}$. Improved knowledge of TC's structure \& associated thermodynamics will improve the forecasting techniques of TCs over the BoB and this study may be helpful for this purpose.

\section{Methodology}

Data used

The Global Final (FNL) analysis data (6 hourly) on $1.0^{\circ} \times 1.0^{\circ}$ grids provided by the National Centre for Environmental Prediction (NCEP) has been used as the initial and lateral boundary condition. The simulated outputs are compared with the observed value from India Meteorological Department (IMD) and are visualized by using Grid Analysis and Display System. The model predicted rainfall is compared to the Tropical Rainfall Measuring Mission (TRMM) 3B42V7 rainfall data.

WRF model description ${ }^{14}$

WRF model is the composition of some fully compressible non-hydrostatic equations with different prognostic variables. Vertical grid coordinate is terrain following and dry hydrostatic pressure. The model uses the Runge-Kutta $2^{\text {nd }}$ and $3^{\text {rd }}$ order time integration schemes. There are several options for spatial discretization, diffusion, lateral boundary conditions and nesting. Model initial conditions are three dimensional for real data and one to three dimensional for idealized data. The model has several options for CP, MP, surface layer physics, atmospheric radiation and planetary boundary layer physics. Fig. 1 represents the selected domain in WRF model for this study and the following table 1 contains the input details of the model.

\footnotetext{
Author for correspondence. e-mail: imsyed@du.ac.bd
} 


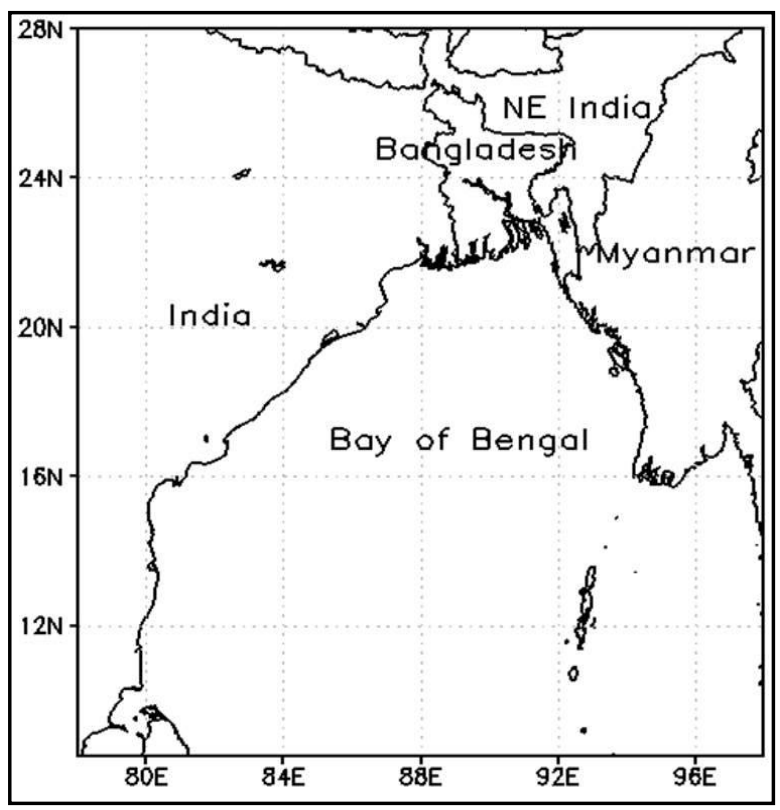

Table 1. List of WRF model inputs and domain configurations

\begin{tabular}{|l|l|l|l|}
\hline $\begin{array}{l}\text { No. of } \\
\text { domain }\end{array}$ & 1 & $\begin{array}{l}\text { Horizontal } \\
\text { grid }\end{array}$ & $\begin{array}{l}\text { Arakawa } \\
\text { C-grid }\end{array}$ \\
\hline $\begin{array}{l}\text { Center of } \\
\text { the domain }\end{array}$ & $\begin{array}{l}17.5^{\circ} \mathrm{N}, \\
87.5^{\circ} \mathrm{E}\end{array}$ & $\begin{array}{l}\text { Time } \\
\text { integration }\end{array}$ & $\begin{array}{l}3^{\text {rd }} \text { order } \\
\text { Runge-Kutta }\end{array}$ \\
\hline $\begin{array}{l}\text { Vertical co- } \\
\text { ordinate }\end{array}$ & $\begin{array}{l}40 \text { sigma } \\
\text { levels }\end{array}$ & Microphysics & $\begin{array}{l}\text { WSM 6-class } \\
\text { (Hong and } \\
\text { Lim) }\end{array}$ \\
\hline $\begin{array}{l}\text { No. of grid } \\
\text { points \& } \\
\text { Resolution }\end{array}$ & $\begin{array}{l}\text { W-E 100, S-N } \\
100 \& 20 \mathrm{~km}\end{array}$ & CP scheme & $\begin{array}{l}\text { Kain-Fritsch } \\
\text { (new Eta) }\end{array}$ \\
\hline $\begin{array}{l}\text { Run time } \\
\text { (120 hours) }\end{array}$ & $\begin{array}{l}2014-10-8 \text { 00 } \\
\text { to 2014-10 } \\
13 \_00\end{array}$ & PBL scheme & $\begin{array}{l}\text { Yonsei } \\
\text { University } \\
\text { Scheme (YSU) }\end{array}$ \\
\hline $\begin{array}{l}\text { Map } \\
\text { projection }\end{array}$ & Mercator & $\begin{array}{l}\text { Radiation } \\
\text { scheme }\end{array}$ & $\begin{array}{l}\text { RRTM long } \\
\text { wave; } \\
\text { Dudhia's short } \\
\text { wave }\end{array}$ \\
\hline
\end{tabular}

Fig. 1. Selected WRF Model Domain.
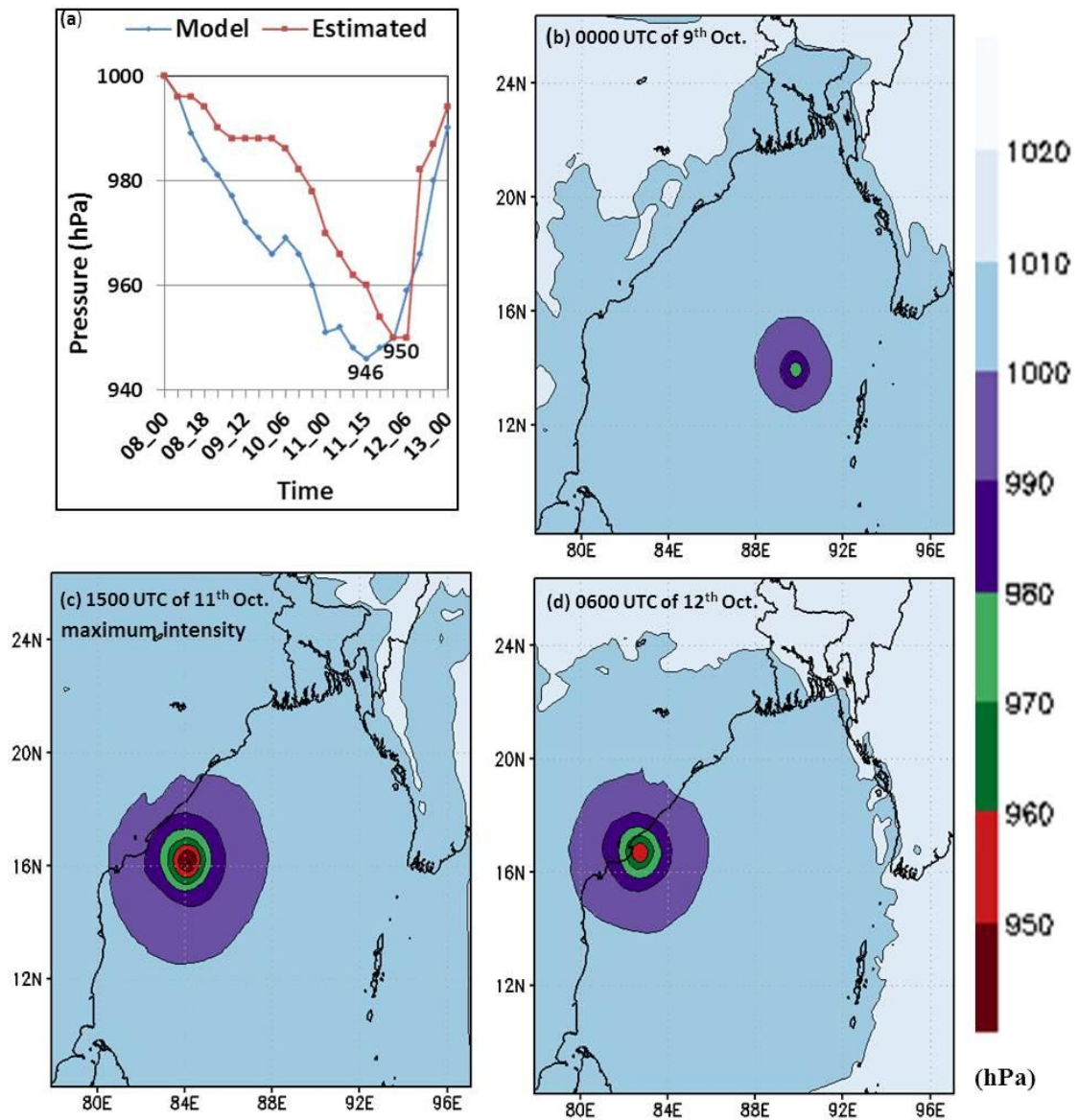

1000

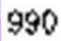

960

950 (hPa)

Fig. 2. (a) Comparison of MCP with the ECP (hPa) ${ }^{15}$. (b) - (d) MSLP (hPa) distribution based on 0000 UTC of $8^{\text {th }}$ October, 2014. 


\section{Results and Discussion}

Mean Sea Level Pressure (MSLP)

Comparison between the time evolution of the Estimated Central Pressure (ECP) ${ }^{15}$ \& simulated Minimum Central Pressure (MCP) of the TC Hudhud (Fig. 2a) shows that the simulated MCP falls more sharply than the ECP. The lowest simulated MCP of $946 \mathrm{hPa}$ and the lowest ECP of $950 \mathrm{hPa}$ are obtained at 1500 UTC of $11^{\text {th }}$ October and 0000 UTC of $12^{\text {th }}$ October respectively. Therefore, the model has predicted intensification of the system 09 hours in advance and overestimates in minimum pressure by only $4 \mathrm{hPa}$ i.e. by only $0.42 \%$ (close to Douluri et al. ${ }^{16}$ ). From the distributions of simulated MSLP (Fig. 2b-2d), the lowest value is found at the center of the TC at its maximum intensity stage (Fig. 2c). At this stage, the system's horizontal size is estimated (considering the outermost closed isobar) around $6.25^{\circ}(663 \mathrm{~km})$ in the east-west (E$\mathrm{W})$ and $6.5^{\circ}(722 \mathrm{~km})$ in the north-south $(\mathrm{N}-\mathrm{S})$ directions. This result identifies Hudhud as an average sized ${ }^{17} \mathrm{TC}$.

\section{Wind flow analysis}

Fig. 3a shows the variations of simulated Maximum Wind
Speeds (MWSs) (at standard meteorological height of $10 \mathrm{~m}$ ) and estimated maximum sustained surface wind ${ }^{15}$ (MSSW) of the TC Hudhud. The highest simulated MWS of $45 \mathrm{~ms}^{-1}$ is obtained at 1500 UTC and the highest estimated MSSW of $51.44 \mathrm{~ms}^{-1}$ is obtained at $1800 \mathrm{UTC}$ of $11^{\text {th }}$ October. So, the model underestimates the highest MWS by $6.0 \mathrm{~ms}^{-1}$ i.e. by $12 \%$ (close to Douluri et al. ${ }^{16}$ ). The horizontal distributions of wind at surface (Fig. 3b-3d) shows strong cyclonic circulation with minimum wind at the center (eye of the TC). Strongest winds of around $30 \mathrm{~ms}^{-1}$ at the initial stage (Fig. 3b) \& 40-45 $\mathrm{ms}^{-1}$ at the maximum intensity (Fig. 3c) both are found in the south-east sector of the TC. Near landfall (Fig. 3d), wind in the front side (northwest) of the system is slightly smaller compared to that in the other sectors due to landmass friction.

At $850 \mathrm{hPa}$ level (Fig. 4), the distribution of wind is almost the same as that of at the surface level except the increase in wind magnitude to a value of around $60-70 \mathrm{~ms}^{-1}$. At 200 $\mathrm{hPa}$ level, the cyclonic circulation is not well defined at the initial stage (Fig. 5a) but at the stage of maximum intensity (Fig. 5b); there is clearly a well-organized cyclonic circulation that makes the TC Hudhud VSCS.

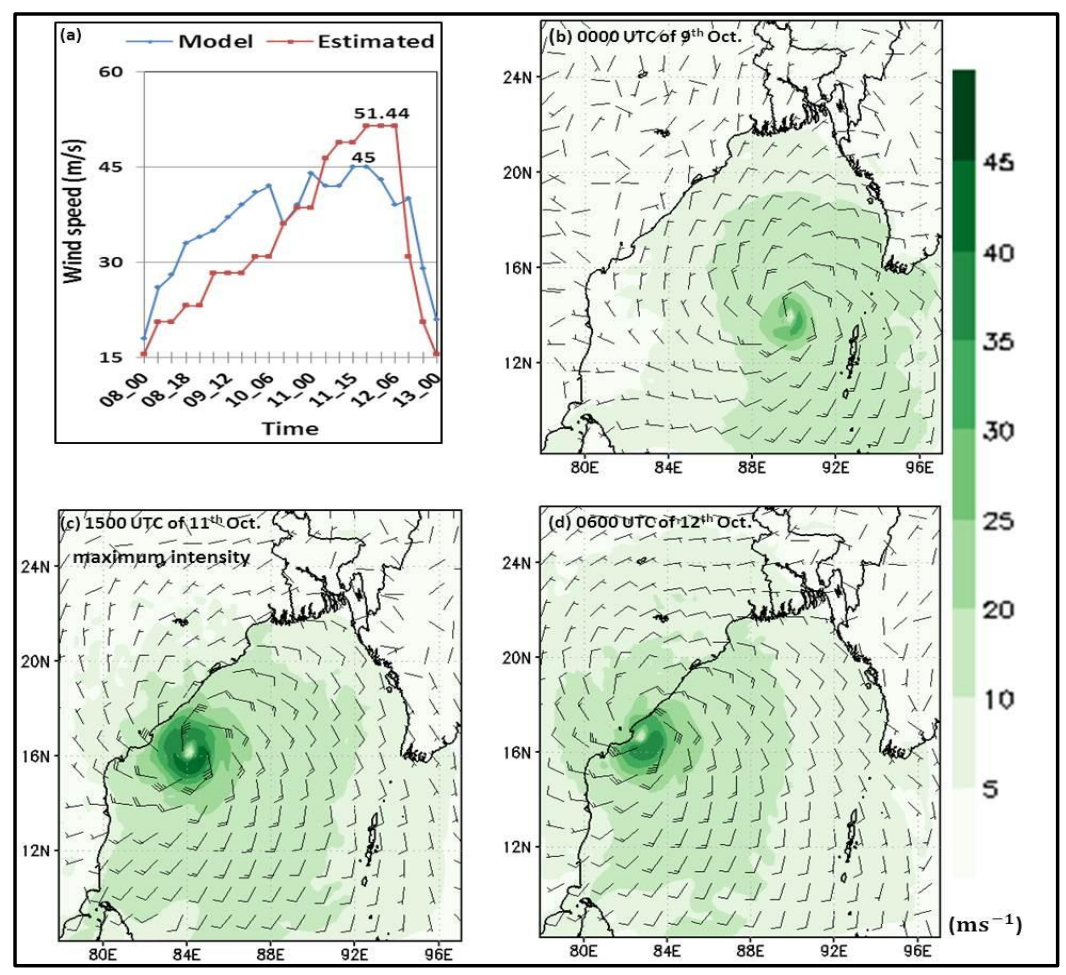

Fig. 3. (a) Comparison of simulated MWS $\left(\mathrm{ms}^{-1} \text { ) at surface with the estimated MSSW (ms }{ }^{-1}\right)^{15}$. (b) - (d) wind distribution (speed in $\left.\mathrm{ms}^{-1}\right)$ at surface based on 0000 UTC of $8^{\text {th }}$ October, 2014. 


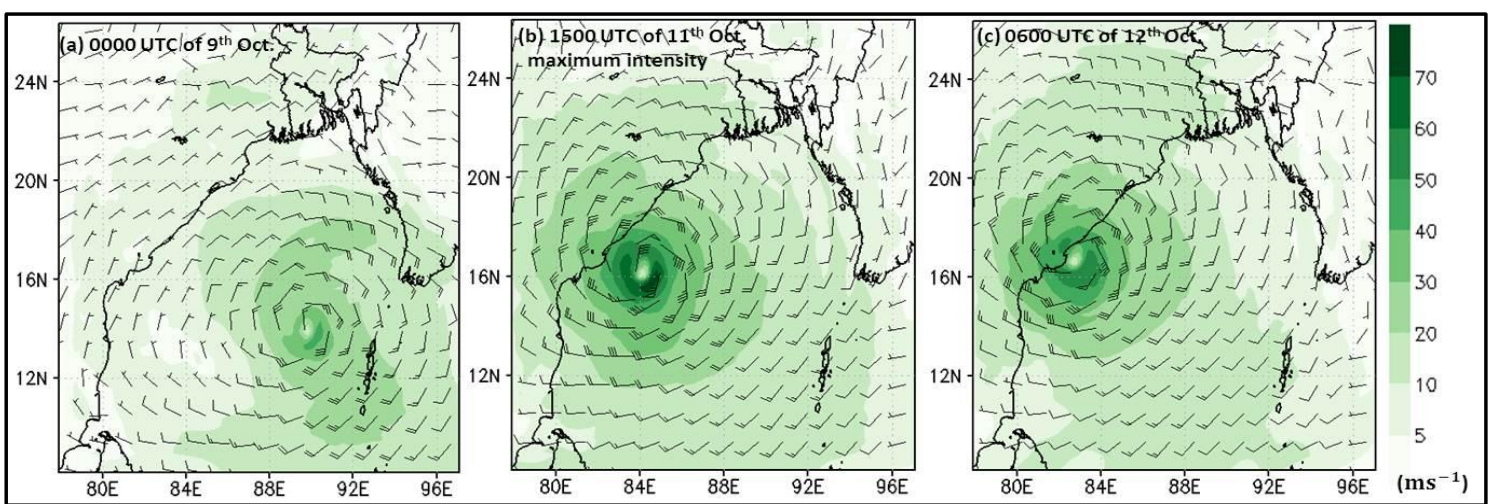

Fig. 4. Wind distribution (speed in $\mathrm{ms}^{-1}$ ) at $850 \mathrm{hPa}$ level based on $0000 \mathrm{UTC}$ of $8^{\text {th }}$ October, 2014.

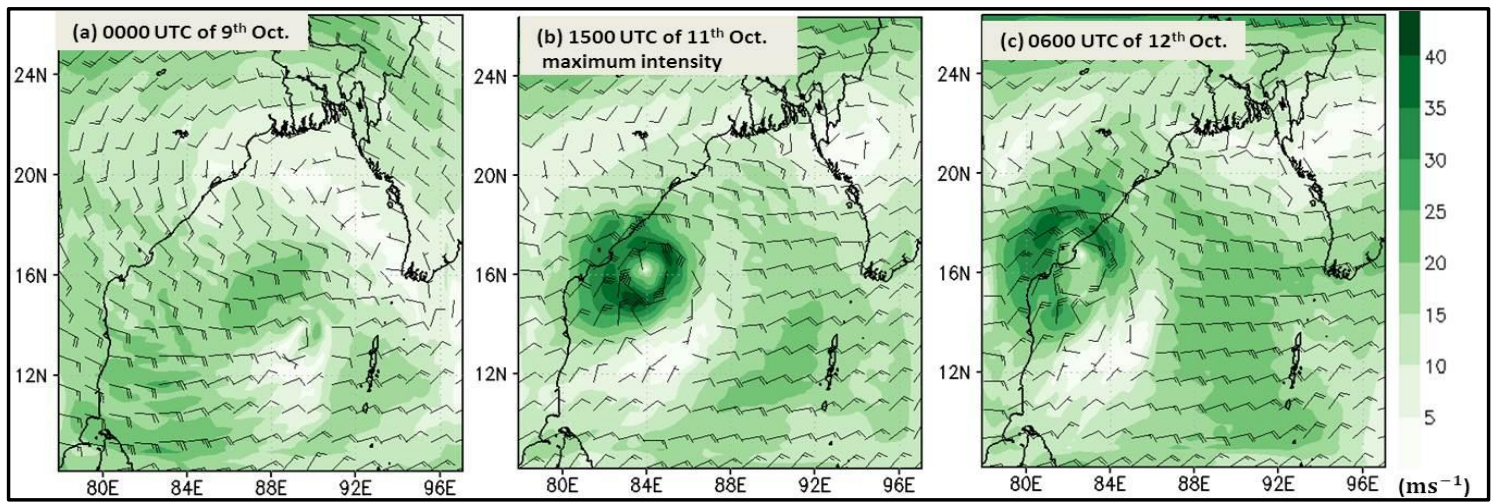

Fig. 5. Wind distribution (speed in $\mathrm{ms}^{-1}$ ) at $200 \mathrm{hPa}$ level based on $0000 \mathrm{UTC}$ of $8^{\text {th }}$ October, 2014.

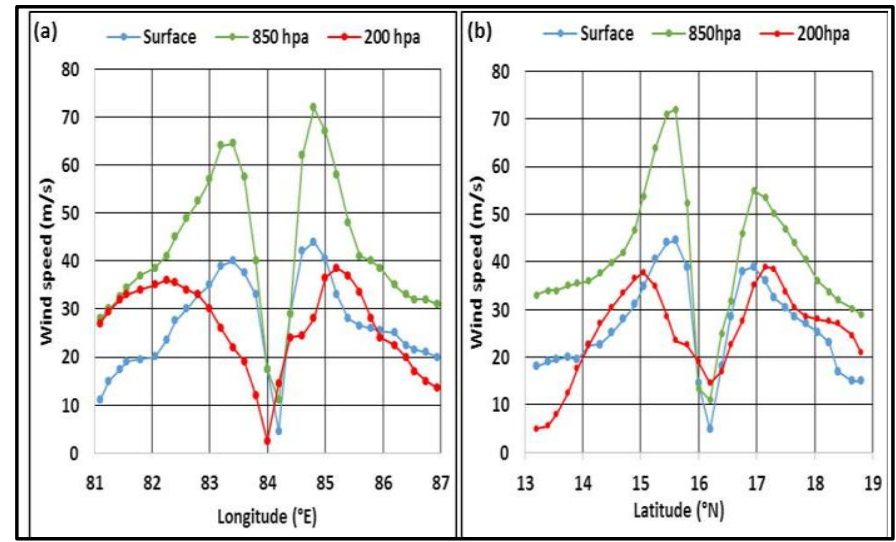

Fig. 6. Wind speed distribution $\left(\mathrm{ms}^{-1}\right)$ at 1500 UTC of $11^{\text {th }}$ October (maximum intensity), along the center $\left(16.19^{\sqrt{2}} \mathrm{~N}, 84.18^{\mathrm{g}} \mathrm{E}\right)$.

Fig. 6 ((a) E-W, (b) N-S) shows the distributions of simulated wind of the TC Hudhud passing through its center at 1500 UTC of $11^{\text {th }}$ October, 2014 (maximum intensity). The central region is relatively calm with feeble wind compared to that in the surrounding eyewall of the system. The radius of maximum wind of the system at surface, 850 $\mathrm{hPa}$ and $200 \mathrm{hPa}$ are found to be around 60,60 and $110 \mathrm{Km}$ respectively. 


\section{Relative vorticity}

The horizontal distributions of simulated relative vorticity (Fig. 7) at $850 \mathrm{hPa}$ associated with the TC Hudhud shows positive relative vorticity close to the center that indicates strong cyclonic circulation ${ }^{18}$ which contributes to the severe convective activities to maintain the supply of moisture into the system. The vorticity increases following the development of the TC and it is maximum (around
$240 \times 10^{-5} \mathrm{~s}^{-1}$ ) at the stage of maximum intensity (Fig. 7b). At $200 \mathrm{hPa}$ level (Fig. 8), joint distribution of weak positive vorticity (around $110 \times 10^{-5} \mathrm{~s}^{-1}$ ) along with negative vorticity indicates cyclonic circulation up to $200 \mathrm{hPa}$ that correspondingly indicate the intensification of the system into a VSCS.

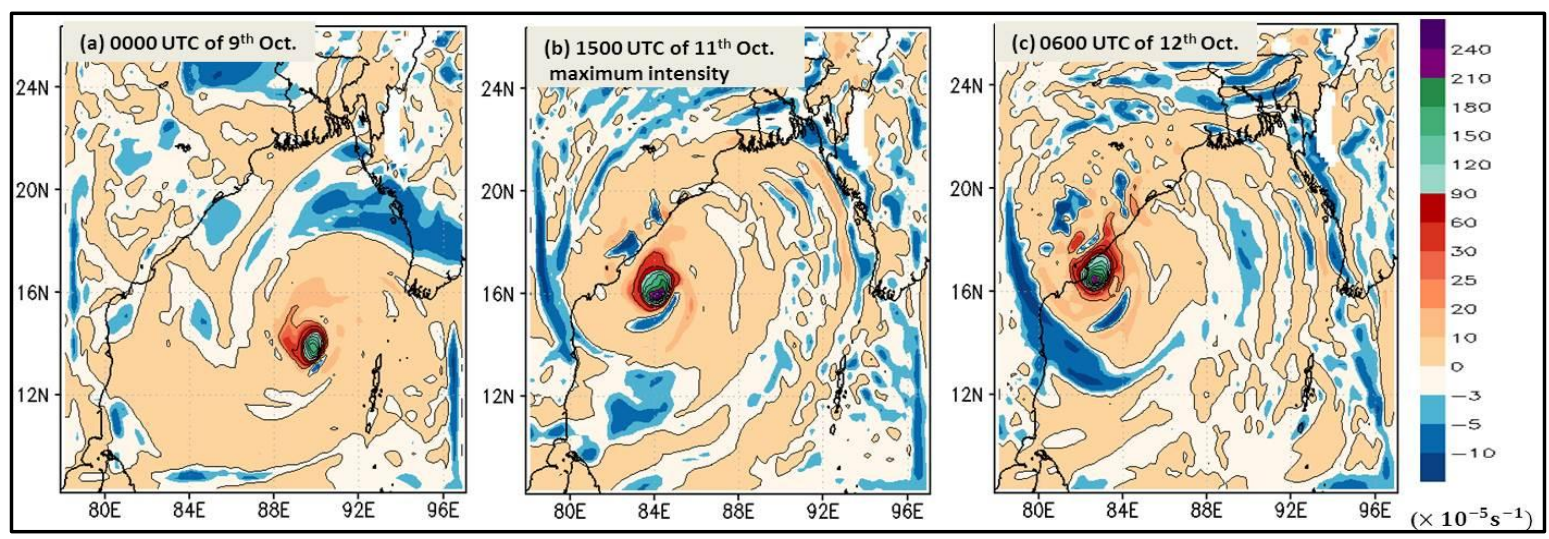

Fig. 7. The distribution of relative vorticity (unit: $\times 10^{-5} \mathrm{~s}^{-1}$ ) at $850 \mathrm{hPa}$ based on $0000 \mathrm{UTC}$ of $8^{\text {th }}$ October, 2014 .

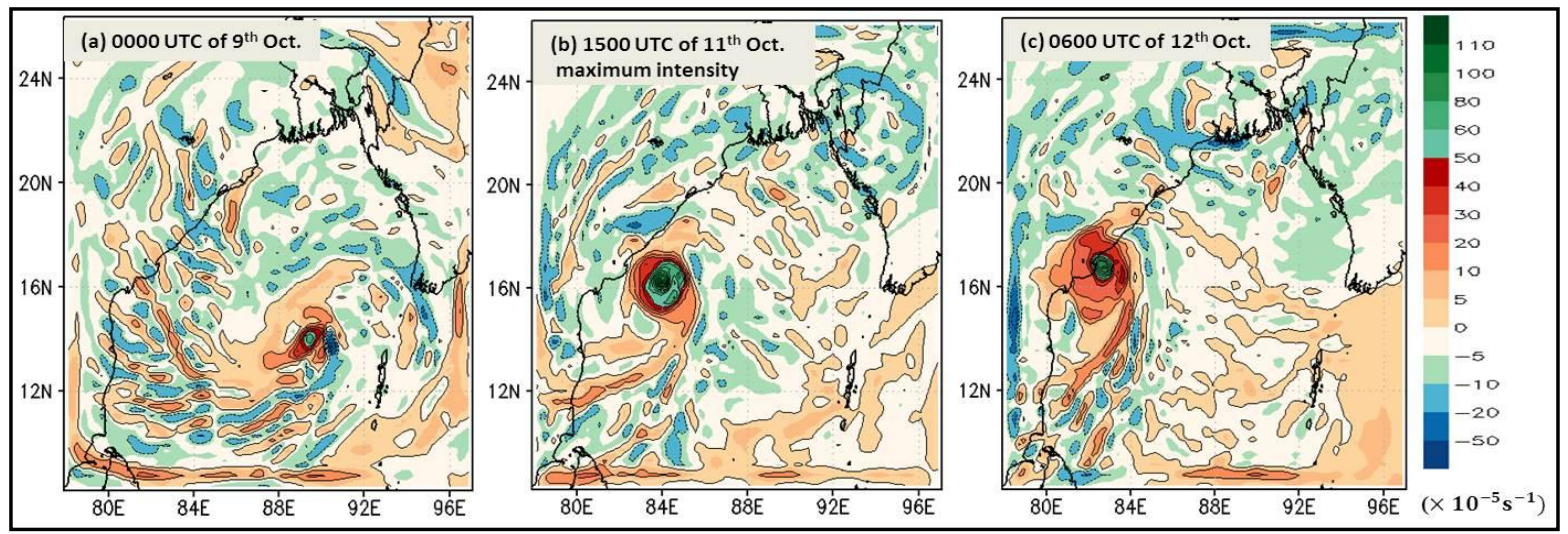

Fig. 8. The distribution of relative vorticity (unit: $\times 10^{-5} \mathrm{~s}^{-1}$ ) at $200 \mathrm{hPa}$ based on 0000 UTC of $8^{\text {th }}$ October, 2014.

Relative humidity $(R H)$ and rainfall

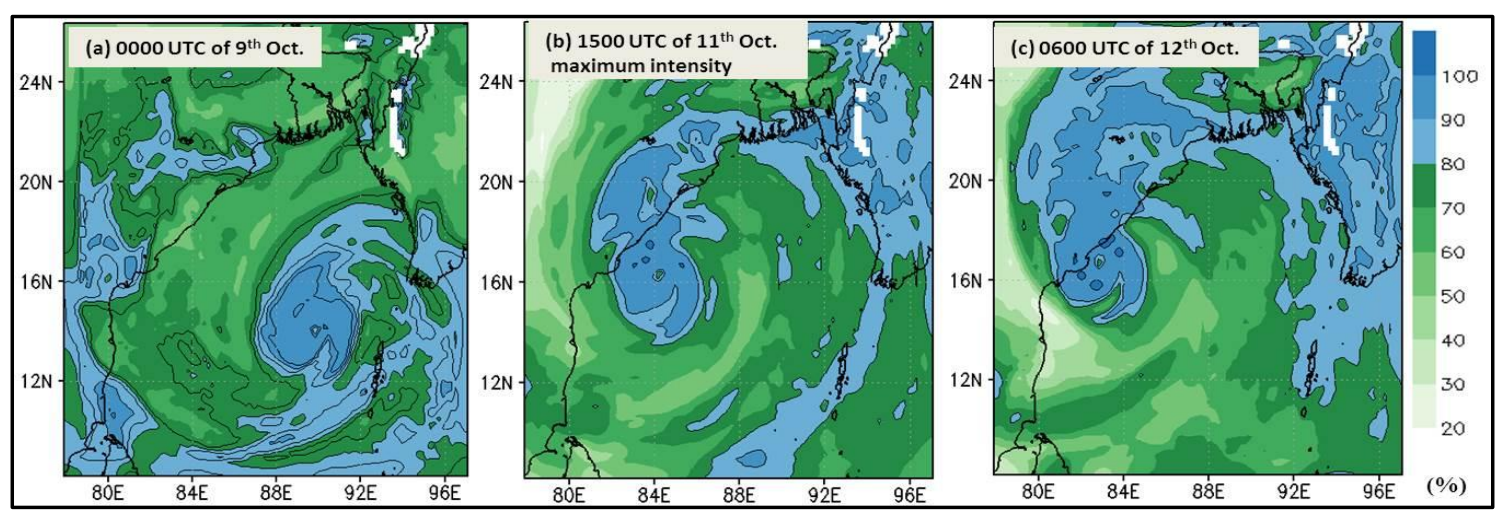

Fig. 9. The distribution of RH (\%) at $850 \mathrm{hPa}$ based on $0000 \mathrm{UTC}$ of $8^{\text {th }}$ October, 2014. 


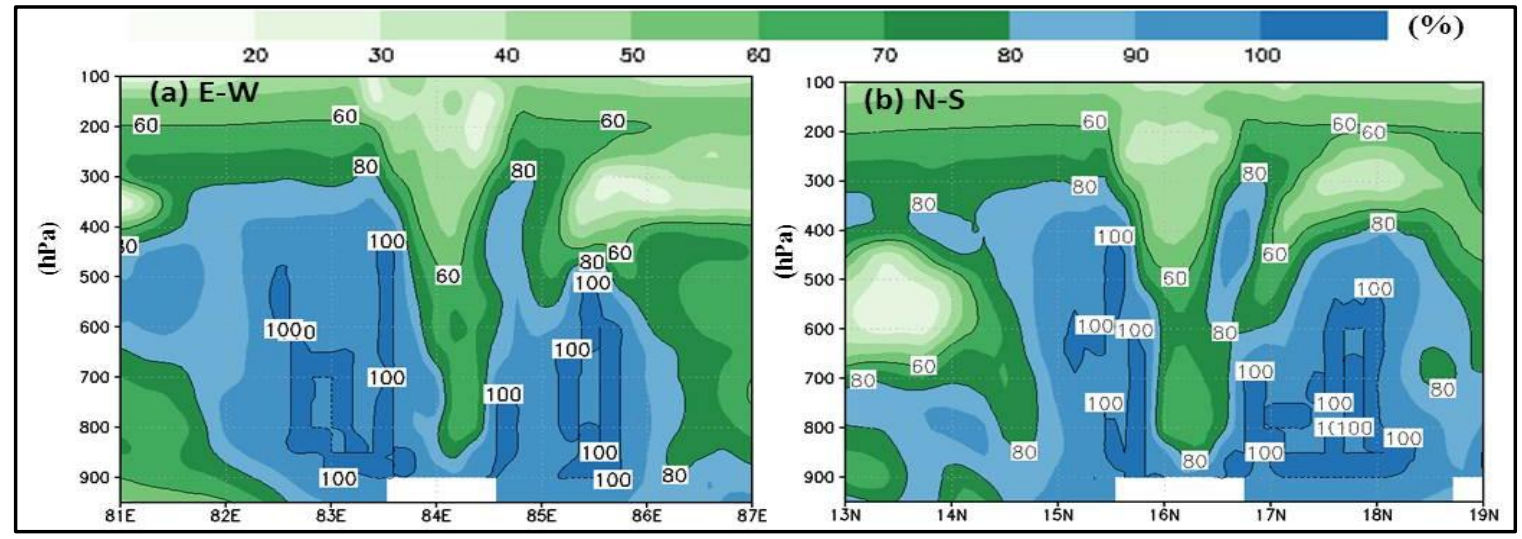

Fig. 10. Vertical profile of RH (\%) at 1500 UTC of $11^{\text {th }}$ October (maximum intensity), along the center $\left(16.19^{2} \mathrm{~N}, 84.18^{2} \mathrm{E}\right)$.

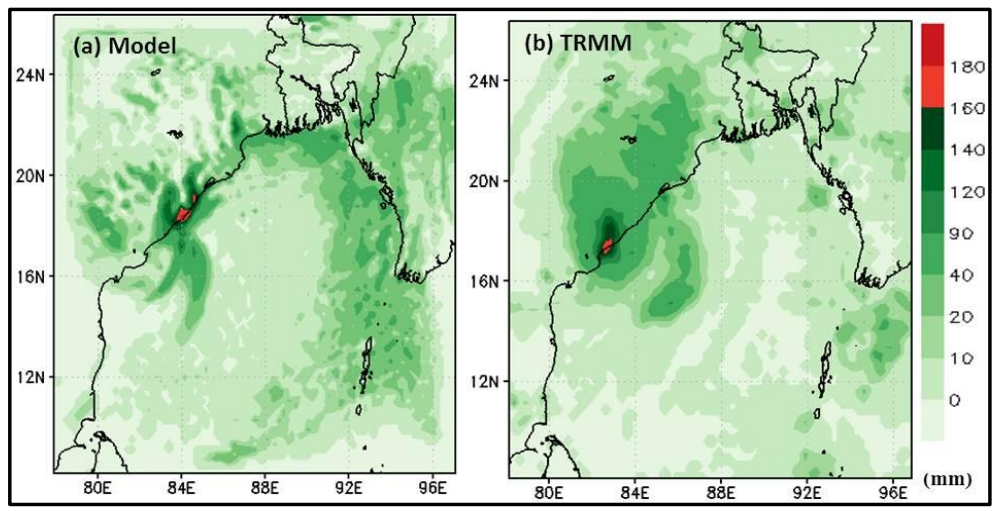

Fig. 11. Comparison of (a) simulated and (b) TRMM 24 hour accumulated rainfall (mm) on $12^{\text {th }}$ October (landfall day), 2014.

The horizontal distributions of $\mathrm{RH}$ at $850 \mathrm{hPa}$ (Fig. 9) indicate that southeasterly flow associated with the TC transports huge amount of moisture (80-100 \%) which is favorable for heavy rainfall events near landfall. The vertical profile of $\mathrm{RH}$ along the center (Fig. 10) at 1500 UTC of $11^{\text {th }}$ October (maximum intensity) shows lower values of $\mathrm{RH}$ at the center than the surroundings. Large $\mathrm{RH}$ (> $80 \%$ ) along the center of the system is extended up to $850 \mathrm{hPa}$. Above $500 \mathrm{hPa}$ the air is relatively dry $(\mathrm{RH} \leq 50$ $\%)$. But in the peripheral region, high RH (90\%) is maintained up to $400 \mathrm{hPa}^{19}$.

The comparison between the spatial distribution of simulated and the TRMM 3B42V7 24 hour accumulated rainfalls (Fig.11) on $12^{\text {th }}$ October (landfall day) shows that model simulated and TRMM rainfalls are nearly in good agreement in both spatial and quantitative perspective.

\section{Zonal and meridional components of velocity}

The vertical distributions of zonal and meridional wind (Fig. 12) at maximum intensity along the center capture a calm center (the eye) with feeble wind. Strong winds with different magnitudes are confined at different levels. In Fig. 12a, the negative (north side) and positive (south side) zonal velocities indicate easterly and westerly winds respectively. Maximum wind of $60 \mathrm{~ms}^{-1}$ is found to the south of the center that extends vertically from $850-700 \mathrm{hPa}$. In Fig. 12b, the positive (east side) and negative (west side) values of meridional wind represent southerly \& northerly winds respectively. Maximum wind of $60 \mathrm{~ms}^{-1}$ is in between 950 to $800 \mathrm{hPa}$. Wind speed also decreases with increasing distance (radius) from the center ${ }^{19}$.

\section{Vertical component of velocity}

The distributions of vertical velocity component (Fig. 13) at maximum intensity through the center of the TC show both upward (positive) and downward (negative) motions. In the E-W (Fig. 13a) and N-S (Fig. 13b) view, strong updraft with magnitude $0.5-2.5 \mathrm{~ms}^{-1}$ (western side) \& $1-3 \mathrm{~ms}^{-1}$ (southern side) are found respectively along the peripheral region. So, the updraft is relatively stronger in the southwest sector. Upward motion through the troposphere maintains the feeding of necessary moisture to the system. Downdrafts are through the center and the regions in between rain bands of the TC i.e. downdrafts in between the updrafts ${ }^{20}$. 


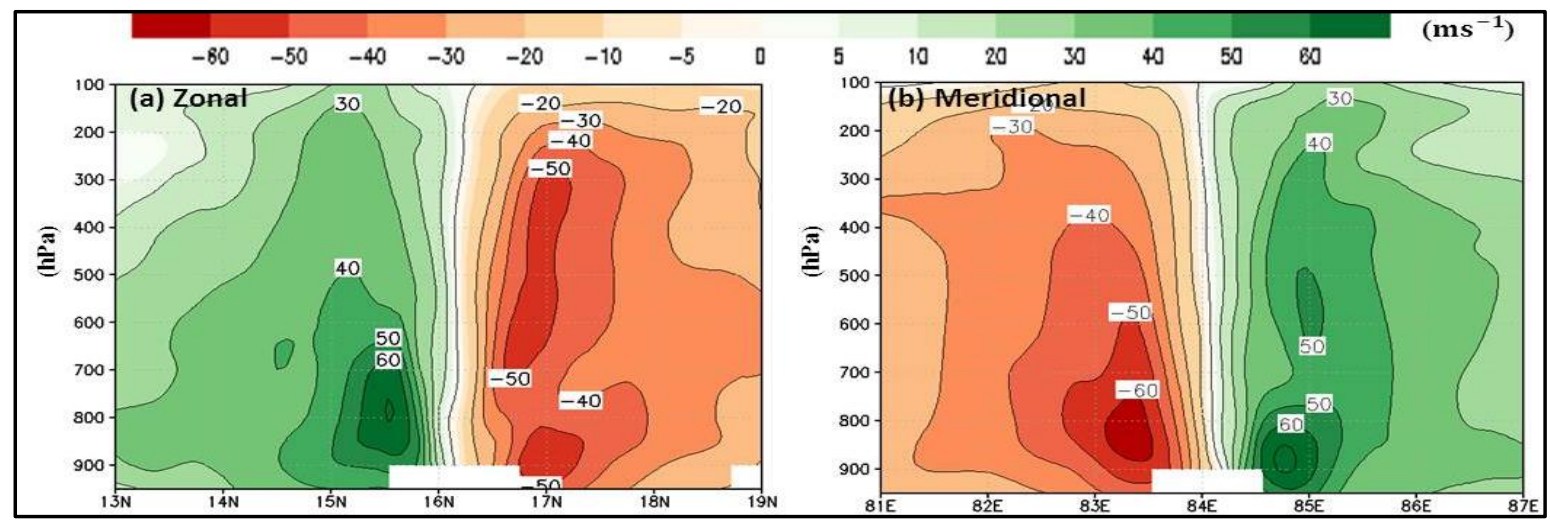

Fig. 12. Horizontal components of velocity at $1500 \mathrm{UTC}, 11^{\text {th }}$ October (maximum intensity) along the center $\left(16.19^{5} \mathrm{~N}, 84.18^{\mathrm{s}} \mathrm{E}\right)$.

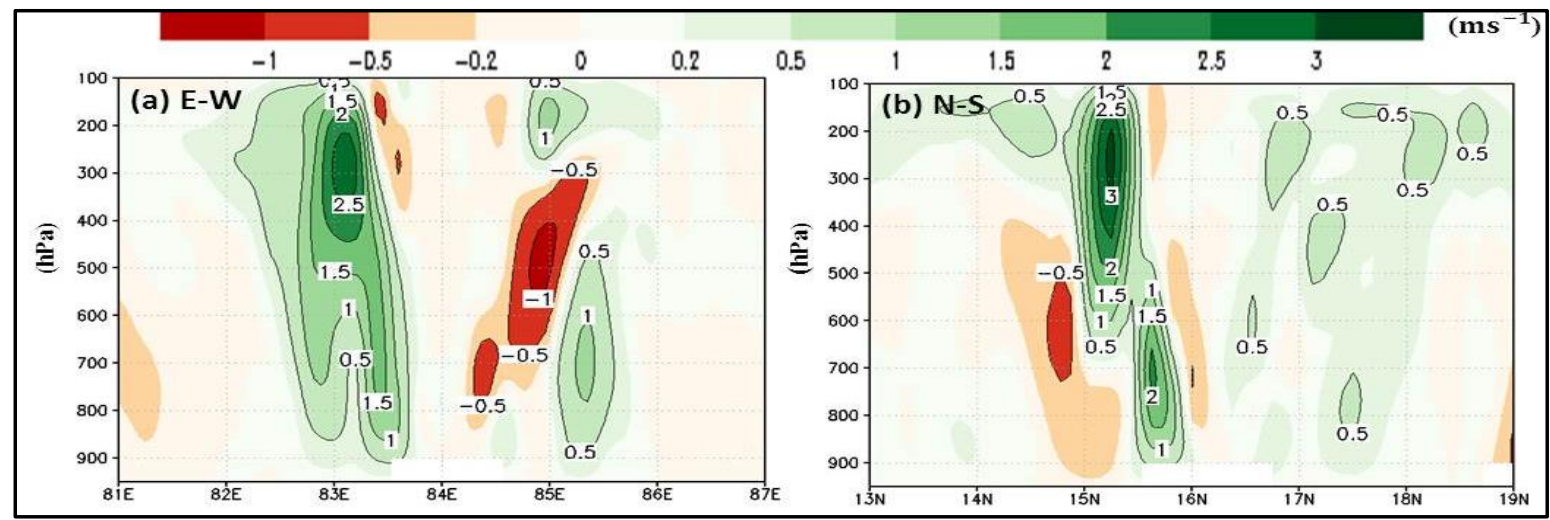

Fig. 13. Vertical component of velocity at $1500 \mathrm{UTC}, 11^{\text {th }}$ October (maximum intensity) along the center $\left(16.19^{2} \mathrm{~N}, 84.18^{2} \mathrm{E}\right)$.

\section{Conclusions}

Lowest MCP for the TC Hudhud is $946 \mathrm{hPa}$ and highest MWS at surface is $45 \mathrm{~ms}^{-1}$. Average horizontal size of the $\mathrm{TC}$ at the most intense stage is found roughly $690 \mathrm{~km}$. The wind speeds are found to be decreasing with increasing height but the size of the TC changes inversely. Favorable $\mathrm{RH}(\geq 60 \%)$ is found between 700 and $500 \mathrm{hPa}$. The wind and relative vorticity distributions show cyclonic circulation up to $200 \mathrm{hPa}$. Large vertical extension (entire troposphere) of the TC is found with strongest winds $\left(60 \mathrm{~ms}^{-1}\right)$ in between 850 to $700 \mathrm{hPa}$. The highest upward velocity is found around $3 \mathrm{~ms}^{-1}$.

\section{Acknowledgements}

The authors are grateful to National Center for Atmospheric Research and National Center for Environmental Prediction for providing the WRF model and analysis data sets respectively. We are also thankful to India Meteorological Department and Joint Typhoon Warning Center for observed data to validate our results.

\section{References}

1. Ali, A., 1999. Ghurnijhar., Bangla Academy, Dhaka, 320.

2. Emanuel, K.A., 1986. An air-sea interaction theory for tropical cyclones. Part I: Steady state maintenance. J. Atoms. Sci. 43, 585-604.
3. Liu, K. S., and J. C. L. Chan, 1999. Size of tropical cyclones as inferred from ERS-1 and 2 data. Mon. Wea. Rev. 127, 2992-3001.

4. Cyclone awareness, RSMC over North Indian Ocean, IMD.

5. Shepherd, T. J., 2008. A Numerical Modelling Study of Tropical Cyclone Sidr (2007): Sensitivity Experiments Using the Weather Research and Forecasting Model, Master's thesis, Department of Geography, University of Canterbury New Zealand.

6. Hawkins, H.F., and S.M. Imbembo, 1976. The structure of a small, intense hurricane-Inez 1966. Mon. Wea. Rev. 104, 418-442.

7. Fovell R. G., and H. Su, 2007. Impact of cloud microphysics on hurricane track forecast, Geophys. Res. Lett., 34, L24810.

8. Merrill R.T., 1988. Environmental Influences on Hurricane Intensification, J. Atoms. Sci. 45 (11), 1678-1687.

9. Hill, K.A., and G.M., Lackmann, 2009. Influence of environmental humidity on tropical cyclone size. Mon. Wea. Rev., 137, 3294-3315.

10. Benjamin, W.G., and F. Zhang, 2014. Sensitivity of Tropical Cyclone Simulations to Parametric Uncertainties in Air-Sea Fluxes and Implications for Parameter Estimation, Mon. Wea. Rev. 142, 2290-2308.

11. Basnayake, B. R. S. B., M. A. R. Akand, and F. F. Nesa, 2010. Structure and movement of Very severe Cyclonic Storms over the North Indian Ocean simulated by WRF-ARW model. SAARC Meteorological Research Centre, Scientific Report No 33. 
12. Imran A., I.M. Syed, S.M.Q. Hassan and M. A. K. Mallik, 2017. Track and Structure of Severe Cyclonic Storm Aila using WRF-ARW. Submitted to Bangladesh J. Phys.

13. Akhter M. A. E., M. M. Alam and M. A. K. Mallik, 2016. Simulation of the structure and track of the TC Rashmi using numerical models, Dew drop, BMD, 2(1), 60-74.

14. Skamarock W.C., J. B. Klemp, J. Dudhia, D.O. Gill, D. M. Barker, M. G. Duda, X. Huang, W. Wang, and J. G. Powers, 2008. A Description of the Advanced Research WRF V3, NCAR Tech. Note NCAR/TN475+STR.

15. Very Severe Cyclonic Storm, HUDHUD over the Bay of Bengal (07-14 Oct. 2014). A Report; Cyclone Warning Division, IMD.

16. Douluri D.L. and K., Annapurnaiah , 2016. Impact of Microphysics Schemes in the Simulation of Cyclone Hudhud using WRF-ARW model. International Journal of Oceans and Oceanography, 10 (1), 49-59.
17. Joint Typhoon Warning Center. 2009. Retrieved May 7, 2009.

18. Holton J. R., An Introduction to DYNAMIC METEOROLOGY, Fourth edition, ELSEVIER ACADEMIC PRESS, 92.

19. Frank W.M., 1977. The Structure and Energetics of the Tropical Cyclone I. Storm Structure. Mon. Wea. Rev. 105, 1119-1135.

20. Liu Y., D. Zhang, and M.K. Yau, 1997. A Multiscale Numerical Study of Hurricane Andrew (1992) Part I: Explicit Simulation and Verification, Mon. Wea. Rev, 125, 30733093. 